\title{
Institutional design for collective and holistic leadership
}

\author{
Torfing, Jacob; Sørensen, Eva; Bentzen, Tina Øllgaard
}

Published in:

International Journal of Public Leadership

DOI:

10.1108/IJPL-12-2018-0059

Publication date:

2019

Document Version

Peer reviewed version

Citation for published version (APA):

Torfing, J., Sørensen, E., \& Bentzen, T. Ø. (2019). Institutional design for collective and holistic leadership. International Journal of Public Leadership, 15(1), 58-76. https://doi.org/10.1108/IJPL-12-2018-0059

\section{General rights}

Copyright and moral rights for the publications made accessible in the public portal are retained by the authors and/or other copyright owners and it is a condition of accessing publications that users recognise and abide by the legal requirements associated with these rights.

- Users may download and print one copy of any publication from the public portal for the purpose of private study or research.

- You may not further distribute the material or use it for any profit-making activity or commercial gain.

- You may freely distribute the URL identifying the publication in the public portal.

Take down policy

If you believe that this document breaches copyright please contact rucforsk@kb.dk providing details, and we will remove access to the work immediately and investigate your claim. 


\title{
Institutional design for collective and holistic political leadership
}

\author{
Tina $\varnothing$ llgaard Bentzen, Eva Sørensen and Jacob Torfing
}

We live in turbulent times in which the pervasiveness of complex societal problems, easy access to digitalized media, and increasingly dispersed expertise are overwhelming the public agenda with demands for new policy solutions. Finding innovative solutions to cross-cutting problems such as climate change, economic slumps, social inequality, inner city decay, public safety risks, etc. requires visionary thinking, pragmatic solutions, bold action and the ability to secure political support in the face of resistance to change. In short, the need for policy innovation calls for a strengthening of political leadership, defined as the ability to identify problems and challenges that require collective action, and to design and implement creative, yet feasible, solutions (Tucker, 1995).

Political leadership is exercised at different levels. World leaders exercise global political leadership by forging international agreements; national political leaders pass legislation that regulates society and the economy; and local political leaders aim to meet the needs of local citizens through a mixture of public service production, local planning and public investments. Local councilors and mayors may not perceive themselves as political leaders (Hendriks and Karsten, 2017). Nevertheless, they perform key political leadership functions such as public agenda setting, pragmatic problem-solving and mobilizing political support (Barber, 2013).

Local councilors' exercise of political leadership is pivotal. Both the well-being of the local population and opportunities for business development depend on policies, services and regulations for which local councilors are responsible. Moreover, the close proximity between local councilors and citizens creates good opportunities for securing input and output legitimacy, thus strengthening trust in government. Finally, local politics is an important arena for recruiting and educating future political leaders.

Local political leadership is essential, yet subject to strong pressures. Local governments are part of a 'multi-level governance system' (Bache and Flinders, 2004) in which power is shifting upwards to national, supranational and international decision-making arenas, while new service demands and budget cuts are shifting downwards to municipalities that are struggling to make ends meet. At the same time, political decisions are subject to negotiations in tangled networks in which power is distributed and nobody seems to be in charge (Sørensen and Torfing, 2007; Bryson and Crosby, 2005). Finally, yet importantly, local politicians aiming to exercise political leadership face tough competition from strong professional administrators (Pierre and Peters, 2004) and from competent, assertive and critical citizens (Nye, 2008; Dalton and Welzel, 2014).

The current institutionalization of interaction between politicians, administrators and societal actors adds to the feeling of powerlessness shared by many local politicians. A recent report about the working conditions of local councilors in Denmark shows that elected politicians suffer from isolation, decoupling, and tunnel vision (Kjær and Opstrup, 2016). Isolation results from the tendency of local councilors to spend more time in council and committee meetings prepared by the administration than in meetings with local citizens and stakeholders. Decoupling stems from the late involvement of local politicians in the development of public policies that public managers have initiated and formulated but which councilors must endorse. Finally, tunnel vision comes from spending a large amount of time and energy processing cases in political committees that mirror the administrative division of labor and, therefore, provide a narrow, sector-specific perspective on problems that call for political leadership. 
Local councilors seem determined to respond to these pressures by transforming the institutional conditions for the exercise of political leadership. Hence, democratic innovation at the local level is ubiquitous (Smith, 2009). A survey of Danish and Norwegian municipalities identified 23 Danish and 22 Norwegian municipalities that had recently reformed their local political institutions (Bentzen, Lo and Windsvold, 2019). With a few exceptions (Elcock, 2001; Mouritzen and Svara; 2002; Berg and Rao, 2005), only scant attention has been paid to how the design of the political institutions of local government influences local councilors' ability to exercise political leadership. To fill this gap, we analyze, compare and assess the efforts of two Danish municipalities to reform their local political institutions in order to improve the conditions for collective and holistic policy development.

While some municipalities aim to counter the isolation of elected politicians by developing an interactive style of political leadership in which policy is formulated in close dialogue with relevant and affected actors from the local community (Sørensen and Torfing, 2019), other municipalities aim to counteract the decoupling of local politicians and the development of tunnel vision by creating collective forums in which local councilors can set the agenda and develop new policies through more or less informal political discussions that cut across sector boundaries and take a holistic approach to addressing the problems and challenges at hand. To learn more about the background, content, functioning and impact of institutional reforms aiming to enhance such collective, holistic political leadership, we conducted a comparative case study of two Danish municipalities that have introduced different institutional designs.

Our study supplements studies of local political leadership reforms that have variously tried to enhance the mayor's power (Wollmann, 2005), introduce cabinet models (Rao, 2005) or consolidate the committee system (Berg, 2005). For that reason, the local reforms that we are studying do not aim to strengthen the executive role of the mayor at the expense of the council members; nor do they seek to create a cabinet consisting of councilors from the majority party coalition only; and they do not aim to solve problems associated with a strong committee system (Berg, 2005). Instead, we chose to study institutional reforms that aim to enhance collective and holistic political leadership in local municipalities by introducing new forums of political deliberation and decision-making. We hope that our findings will inspire reforms in other municipalities.

The article proceeds in the following way. The first section presents the theoretical framework that we use to study local political leadership. The second section contextualizes the empirical analysis by briefly describing the Danish local government system. The third section provides a methodological account of our case selection, data collection and analysis. The fourth section contains our analysis of political leadership reforms in the two municipalities, and identifies similarities and differences in a cross-case analysis. The fifth section reflects on the significance of our findings and draws lessons from these different attempts to use institutional design to improve the conditions for collective and holistic political leadership. The conclusion summarizes the findings and points to some future research avenues.

\section{Theoretical framework for studying local political leadership}

Public leadership is not merely exercised in the political domain, but coexists with administrative, judicial and civic leadership ('t Hart and Uhr, 2008). However, in representative democracy political leadership plays a key role in connecting policy outcomes to the needs and demands of the people. Politicians compete for votes by presenting more or less coherent political programs and election pledges to the public, and they often continue to interact with party members and their local constituencies after they have become elected. How much elected politicians get to influence policy outcomes and align them with 
social demands depends, among other things, on their opportunities for dealing with key political issues, their access to dialogue with citizens and stakeholders, and their ability to monitor policy implementation.

There is an unfortunate tendency to reduce the study of political leadership to the study of individual leaders and their more or less charismatic personalities and heroic deeds. Our analysis takes a functionalist approach to the study of political leadership. In ancient Greek philosophy, political leadership was associated with a rule-bound display of sovereign authority based on virtue, prudence and knowledge of the common good (Keohane, 2014). Machiavelli dissociated political leadership from virtue, prudence and the pursuit of the common good, which he believed would end up jeopardizing the exercise of stable political rule. As such, political leadership is reconceptualized as a realist power game in which it is better for the sovereign political leader to be feared than liked (Machiavelli, 1961). More recently, however, Burns (1978), Nye (2008) and Keohane (2014) have warned us not to equate political leadership with the exercise of power. Their argument is that many powerful actors do not exercise leadership in the sense of helping a group to create and achieve a shared goal. Political leaders generally exercise power, but they do so in order to 'orient and mobilize others for a purpose' (Nye, 2008: 19), and the power they use tends to be the 'soft power' of persuasion, charisma and identity construction rather than a 'hard power' based on rewards and punishment (Nye, 2008: 29-31). Liberal democracies characterized by a horizontal distribution of power and the emergence of critical and independent followers encourage political leaders to persuade their followers rather than trying to command or repress them.

Political leaders use persuasion to orient and mobilize followers for a purpose, and their success depends on their ability to undertake three political leadership functions:

1. Identifying and diagnosing the problems of the political community that call for collective action

2. Designing and prescribing bold, yet feasible, solutions to the identified problems

3. Mobilizing political, administrative and popular support for policy decisions and their subsequent implementation (Tucker, 1995).

Different actors, including community leaders, political movements, academics, artists and clerics with the status of 'public intellectuals' may exercise political leadership by performing these three basic leadership functions. However, elected politicians are expected to play a pivotal role as political leaders because they have pledged to enable the political community to create and achieve shared goals and are bestowed with a popular mandate to govern on behalf of the political community until the next election, when they will be held to account for their performance. However, there is no guarantee that elected councilors will undertake these political leadership functions and actually act as political leaders in practice. They may never speak up in order to define problems, advocate solutions, or generate support, or they may only do so sporadically, weakly and without any real impact in terms of enabling the political community to move forward.

Our analysis focuses on the institutional conditions for local councilors' exercise of political leadership. Since Weber (1978) developed his classical bureaucracy model that anchors political leadership in legalrational authority, it has been widely accepted that political leadership is conditioned by the design of formal political institutions as well as the informal political culture embedded in those institutions (Stone, 1995; Elcock, 2001; Helmke and Levitsky, 2004; Peters, 2012; Ayres, 2017). Political institutions are here defined in terms of the rules, procedures, routines, norms, values and discursive forms of knowledge that enable a stable reproduction of political leadership practices by prescribing a particular logic of appropriate action (March and Olsen, 1995). The design of political institutions involves an intended change of the institutional context as opposed to an accidental or evolutional change (Goodin, 1996). 
In local government research, Mouritzen and Svara (2002) have shown how political institutions influence the exercise of political leadership by regulating the distribution of power and determining who decides what, when and how. Building on this insight, Berg and Rao (2005) developed an analytical framework for studying the impact of institutional design on: 1) recruitment of elected councilors; 2 ) involvement of elected councilors in political decision-making; 3 ) interaction between elected councilors and professional administrators; and 4) political accountability of elected councilors in and between elections.

We are particularly interested here in how elected councilors are involved in different kinds of decisionmaking. Berg and Rao (2005: 5) distinguish between elected councilors' involvement in overall steering and control, problem-driven policy-making, and administrative case processing where they assist professional administrators in make detailed and often person-related decisions about service provision. Other tasks include physical planning, budget adjustments and endorsement of contracts with private service providers. Local institutional designs determine what kind of decisions local councilors are involved in and where and how this involvement occurs. Our claim is that early involvement of elected councilors in problem-driven policy-making will tend to strengthen their political leadership.

Political institutions may favor some politicians over others when it comes to participating in policy development. In some countries, political power is placed in the hands of strong mayors, leaving lay politicians with considerably less power (Wollmann, 2005), whereas in other countries political power is concentrated in a cabinet, a finance committee or a committee system. In countries where standing political committees play a key role in the preparation of sector-specific council decisions, there is a danger that policy development will become locked into small political compartments where only a limited group of politicians are involved in political decision-making, and where the administrative and technical nature of those decisions crowds out politics and hands over considerable power to professional administrators.

In response to this danger, New Public Management reforms have aimed to move elected politicians away from detailed, sector-specific and administrative case processing and towards overall steering and control based on strategic management (Osborne and Gaebler, 1993). However, the somewhat abstract exercise of goal and framework steering tends to have limited appeal for local councilors who cling to the sectorspecific case processing that seems to provide a concrete and manageable task (Elcock, 2001; Sørensen and Torfing, 2013). Hence, our claim is that new designs that favor the broad collegial participation of lay politicians in deliberative forums that cut across permanent committees are needed to enhance collective and holistic political leadership.

Political institutions determine which issues local councilors can influence politically and who has this influence. Hence, developing collective and holistic political leadership calls for institutional designs that involve as many politicians as possible in the early phases of problem-focused policy development. At a more concrete level, such institutional designs may provide time and space for informal, cross-boundary agenda setting and open-ended discussion of whether to deal with a particular societal problem or challenge, and what to do about it. The responsibility for creating such discussion forums and decisionmaking arenas lies with the elected councilors. As such, it falls within the remit of political leadership to reflect upon and try to improve the conditions for exercising political leadership.

The analytical implications of this for our analysis are that we will search for, and carefully describe, institutional designs intended to enhance collective and holistic political leadership. We will account for the background and content of the new institutional designs, analyze their performance in terms of the political interaction they engender, and assess their impact on the exercise of political leadership. The next section describes the institutional context for our qualitative case studies. 


\section{Local government in Denmark}

The Danish local government system is constitutionally grounded and regulated by the Local Government Act passed by the national parliament (KL, 2018). Since the amalgamation reform in 2007, Denmark has had 98 municipalities and five regions. The local municipalities have the delegated responsibility for delivering public services and transfer payments in the areas of social security, employment, education, health, etc. The municipalities are not only responsible for service provision, social benefits, physical planning, business promotion etc., they also set the agenda for local community development and-within certain boundsthey have a statutory right to take new initiatives and provide public facilities that are not prescribed by national legislation. Around two thirds of the public budget is channeled through the municipalities, making Denmark one of the most decentralized welfare states in the world. The public revenues of Danish municipalities come from a combination of local income taxes, operating and capital revenues, reimbursement from the state, and general subsidies from the national government.

Each municipality is led by an elected council. Elections are held every fourth year and all Danes and local residents from the European Union, Norway and Iceland above the age of 18 years can stand as candidates and vote. The number of elected councilors varies between 9 and 31. Only the city council in Copenhagen has 55 councilors. Each council elects a chairman among its members, who becomes a full-time mayor. It is the mayor's duty to prepare, call and chair all council meetings. The mayor is the chief executive of the local administration, but shares executive power with the elected councilors.

Each municipal council must set up a finance committee that is chaired by the mayor. The members of the finance committee are normally drawn from the political majority that supports the mayor, but-as we shall see-they may also consist of the chairs of the permanent committees appointed by the political majority. The permanent committee structure varies a lot across municipalities. However, municipalities typically have a social services committee, a planning committee, a school committee and a culture and leisure committee. The committee structure reflects the administrative division of labor between different administrative departments (Berg, 2005). The committee system plays an important political role since, based on recommendations from the executive administrators, the committees process cases within their specific areas and then make their own recommendations to the finance committee and the council. These recommendations are usually followed without much discussion.

Every municipality has a professional, merit-based administration that prepares the council's decisions and implements them, and does the same for the national legislation that the municipalities are responsible for. The administrative CEO works closely together with the mayor and leads the executive administrative leadership group that consists of the directors from the administrative departments. The asymmetry between the permanent, well-educated and highly professional administration and the council that consists of hobby politicians who only receive a modest remuneration, clearly tilts the power balance towards the former. However, there is often good teamwork between the mayor and the administrative CEO who is hired by the elected council on a fixed-term contract.

The amalgamation reform, which created bigger municipalities $(55,000$ inhabitants on average) with greater distance between citizens and elected councilors, has stimulated the search for institutional designs enabling local politicians to exercise clear and visible political leadership (Kjær and Opstrup, 2016). As a result, some Danish municipalities form thematic ad hoc committees with the participation of councilors, citizens and local stakeholders in order to develop new solutions to pressing problems through sustained interaction, while other municipalities aim to strengthen the strategic leadership role of the elected council by empowering local communities to manage local problems on their own, e.g. through neighborhood councils and participatory budgeting. The two municipalities we study here chose a different path, aiming instead to promote collective and holistic political leadership. 


\section{Methodological account of case selection, data collection and analysis}

Identifying suitable cases of institutional reforms that aim to enhance collective political leadership that, in turn, enables holistic policy-making, was like finding a needle in a haystack. The first step was to ask a Delphi panel consisting of Danish researchers and practitioners to name municipalities that they knew had been reforming the institutional conditions for political leadership. The Delphi study was supplemented by crowdsourcing using online news media targeting municipalities, in order to recruit those that had recently reformed the conditions for local political leadership. Finally, we asked all the municipalities identified to name other municipalities with a similar agenda. The result was a total of 23 municipalities out of 98 that had allegedly been reforming their political institutions with the aim of strengthening political leadership.

The second step was a careful scoping out of each of the 23 municipalities. We canvassed their webpages to see what kind of institutional changes they had introduced, and we interviewed the administrative head of the local council secretariat to learn more about the reforms. The 23 municipalities that we scoped out had introduced 59 reforms altogether. The majority of those reforms aimed to involve citizens and local stakeholders in local policy development with a view to promoting 'interactive' political leadership. However, we also identified a handful of municipalities that had aimed to strengthen the 'sovereign' political leadership of the elected councilors as a whole. Two municipalities stood out because their reforms aimed to bring councilors from all political parties together in a forum where they could develop political solutions to cross-cutting problems and challenges through political deliberation. The reforms introduced by the two municipalities are unique in the sense that no other Danish municipalities have introduced similar institutional designs.

We decided to conduct a qualitative case study of the two frontrunners. Our purposeful case selection and the uniqueness of the two cases prevent us from generalizing the results to a larger population. However, the case studies allow us to draw important lessons about whether and how institutional design can solve the problem of the political decoupling of elected politicians due to their late involvement in the policy process, as well as the problem of tunnel vision stemming from councilors' involvement in sector-specific committees. If the lessons are positive and the institutional designs are easy to reproduce, the empirical cases may serve as beacons of local polity innovation that can inspire other municipalities to adopt similar institutional designs in order to enhance collective and holistic political leadership (Sørensen, 2017).

Table 1 compares the two municipalities. While the number of councilors and permanent committees is similar, Esbjerg and Hedensted differ in size, degree of urbanization, and political orientation. Esbjerg is a big provincial town surrounded by rural countryside, which had a stable liberal local government based on an absolute majority that lasted for a quarter of a century, but which was lost in the recent election that made the liberals dependent on three other right-wing parties. Hedensted is a rural municipality with no big city within its bounds, and political power has alternated between liberals and social democrats, depending on shifting coalitions. The liberal party was in power at the time of our data collection. It was supported by the social democrats, who seized power after the local election in 2017.

Table 1: Comparison of case municipalities

\begin{tabular}{|l|c|c|}
\hline & Esbjerg Municipality & Hedensted Municipality \\
\hline Number of inhabitants & 115,000 & 46,000 \\
\hline Degree of urbanization & High & Low \\
\hline Enlarged by amalgamation in 2007 & Yes & Yes \\
\hline Political majority & $\begin{array}{c}\text { Long-term liberalist rule based } \\
\text { on an absolute majority }\end{array}$ & $\begin{array}{c}\text { Alternating liberal and social- } \\
\text { democratic rule based on }\end{array}$ \\
\hline
\end{tabular}




\begin{tabular}{|l|c|c|}
\hline & & shifting coalitions \\
\hline Number of councilors & 31 & 27 \\
\hline Number of permanent committees & 6 & 6 \\
\hline
\end{tabular}

Besides documents retrieved from the municipal webpage, data collection was based on qualitative interviews. In Esbjerg Municipality, we interviewed the mayor, five councilors from different parties and three public managers. In Hedensted, we interviewed the mayor, six councilors and five public managers. The interviews were semi-structured and focused on the institutional design, its background, its functioning, and its impact on the exercise of local political leadership. We also asked questions about the problems and challenges associated with the particular institutional designs. Most interviews took about an hour. They were subsequently transcribed in order to facilitate systematic coding and analysis.

The interviews identified a number of reforms aiming to strengthen local political leadership. However, here we will only focus on reforms that are relevant for promoting collective and holistic political leadership.

\section{The background, content, functioning and impact of local political leadership reforms}

\section{Esbjerg Municipality}

Esbjerg is a relatively large municipality that has used its harbor and offshore energy production to stimulate economic growth and job creation. Nevertheless, there is an unresolved budgetary problem and a political ambition to increase the number of inhabitants by providing top-quality services and improving the quality of life. Strategic planning is being introduced to deal with this inherent two-fold pressure, which requires strong political leadership.

The institutional design aiming to support political leadership is not a recent invention. It was introduced in 1990 by the then social-democratic mayor who was persuaded to share power with the liberal party in order to deal with socioeconomic challenges. When the liberal party took over four years later, it inherited the new institutional design that brings together members from all parties in an executive finance committee that operates between the standing committees and the council assembly. The new liberal mayor has retained this arrangement for two reasons. First, he explains: 'I want to have as many as possible on my team and they don't have to have the same political party affiliation as me. I want to have as many councilors behind me as possible in order to be able realize my political objectives'. This quotation demonstrates that strong personal political leadership is a motivating factor behind the institutional design in question. Second, the mayor adds that it is important that the committee chairs 'do not merely perceive themselves as representatives of their administratively defined policy areas. They should also be able to see what is good for the municipality as a whole. Their heart may beat for their political party, but they should also take responsibility for the overall development of the municipality'. Hence, it is not only about strengthening collective political leadership by getting other politicians on the team, but also about having a more holistic view of politics.

The finance committee plays a special role in Esbjerg. Since 1990, the municipality has been the only municipality in the country to have chosen the governance model described in $\S 65$ of the Danish Local 
Government Act, ${ }^{1}$ according to which the finance committee consists of the mayor, two lay politicians and a chairmen of all the standing committees. The committee chairs are not appointed by the political majority as they normally are, but are selected based on the proportional council representation of the different party alliances that subsequently distribute the chairmanships amongst the different parties in the alliance. This particular institutional design means that there are committee chairs, and thus finance committee members, from all parties. The political parties typically appoint their local party leader as committee chair and finance committee member. Hence, the finance committee tends to constitute an executive committee of party leaders. Unlike in the cabinet model, the members of the executive finance committee are drawn both from the majority party and the minority parties. As such, the finance committee is more a mini-council than a cabinet.

The executive function of the finance committee lies in the fact that unlike the standard procedure where the standing committees, based on recommendations from the administration, make their own recommendations directly to the elected council, these recommendations now pass through the finance committee that processes all cases before they are discussed and voted on in the elected council.

The finance committee meets for 1-2 hours per week, 11 months per year. Party group meetings are held half an hour before the finance committee meetings. The executive public managers are present at the meetings to answer technical questions. The meetings have a formal and executive function as they reevaluate all recommendations by the standing committees and may modify them before they are passed on to the elected council. However, the meetings also have an informal function in that considerable time is spent 'outside the agenda' on information sharing, early warning about new plans and initiatives in the standing committees, and discussion of things that have come up in the local or national news media or elsewhere. Topics can range from a Facebook comment from a citizen, to a letter from private developers or a new government initiative to move ministerial jobs to the provinces. Both the formal and informal parts of the meetings focus on political decision-making rather than problem definition, idea generation and strategic planning. As one of the administrative leaders observed: 'The finance committee is not really a forum for policy development'.

Policy development mainly takes place in relation to the annual budget negotiations or when the mayor and other leading politicians, together with external actors, launch new projects or ideas, such as the building of skyscrapers in the town center. On the whole, the councilors' contribution to policy development appears to be limited. The new strategic plan Vision 2020 seems to enjoy widespread political support, but was initiated and drafted by the administration and the executive leadership group.

There is ample room for cross-sector discussions in the finance committee, and these may continue outside the meetings since all the committee chairs have their own offices and spend considerable time in the city hall where they are available for informal conversations.

The formal part of the finance committee meetings focuses on making recommendations to the council meetings, and is a fairly standard decision-making process. The process in the informal part of the meetings

\footnotetext{
${ }^{1}$ Esbjerg has chosen what is commonly referred to as the 'middle model' that lies between committee model and the magistrate model found in the four largest cities in Denmark. Unlike the committee model in which the standing committees have considerable political power within a unitary political-administrative system, the middle model mitigates the power of the standing committees by giving the finance committee a mediating and coordinating role. Unlike the magistrate model in which political and administrative power is divided among several mayors and their administrative directors, and in which the standing committees only have an advisory role, the middle model preserves the unitary system, but reduces the power of the committees without stripping them of their ability to make political recommendations.
} 
is that an issue is raised verbally without preparatory policy papers, and is then discussed openly amongst the councilors. Although different political views and opinions may be expressed both in the formal and informal parts of the meetings, there is a strong inclination to seek consensus and make joint decisions. The mayor is said to be good at give-and-take games, and the discussions usually end with a compromise that most parties can live with.

A major precondition for sharing executive political power in the finance committee is the local tradition for trust-based collaboration between political parties. In Esbjerg, this collaborative culture is evidenced by the annual budget agreements that typically include $90 \%$ of the councilors.

From the perspective of the ruling party, the driver behind the creation of the particular institutional design is to enhance political support for its proposals by integrating councilors from other parties in executive decision-making and to create broad ownership over the overall political course of development by distributing political responsibility to other parties. For the opposition, the main motivation behind its support for the institutional set-up is that it allows them to influence political decisions rather than being sidelined during four long years.

The drivers are matched by at least two barriers. First, strong administrative control and organizational silos limit the scope for collective and holistic policy discussions in the finance committee. The premises for the cross-cutting executive policy discussions in the finance committee are defined by the administrative departments and their respective political committees, and the political committee chairs often defend the interests of the administrative silo they represent, although most of the time they are prepared to adopt a holistic perspective on policy-making. Second, the very high aggregate number of meetings in the council, the committees, and especially the finance committee, weighs heavily on the councilors' time budget and tends to wear them down and prevent them from participating in meetings with citizens and stakeholders that could otherwise generate valuable input for the political process and help to secure support for executive political decisions.

Nevertheless, the councilors both from the ruling coalition and the opposition are satisfied with the current institutional arrangement. It enables the ruling party to gather broad-based political support and ownership, and allows the opposition to garner political influence, not least through its chairmanship of a standing committee. All the councilors seem to benefit from the ability to coordinate political and administrative decisions across sectors and parties.

The administration also benefits. The frequent meetings in the finance committee ensure a good administrative flow because the administration does not have to wait long for political authorization of administrative decisions. The finance committee provides a strong anchorage point for the administration as it issues clear directions for executive leaders to follow. One of the administrators explained: 'The finance committee is a strong partner for the administration. If we have a new initiative and put it on the agenda and get a positive response, we know that it will hold up'.

One of the drawbacks of the power sharing in the finance committee is that it is difficult to make tough decisions that everybody supports. One of the councilors mentioned persistent budget problems in this connection. Making the necessary budget cuts is difficult with the current consensus model, he explained, and would be easier with a majoritarian model.

Another drawback is that the executive finance committee creates a division between an A- and B-team. Councilors belonging to the A-team are the members of the finance committee and enjoy a lot of influence. Councilors belonging to the B-team, which includes around two thirds of the elected council, have little political influence and are basically excluded from collective political leadership. A lay councilor from the 
majority party told us that: 'It is the finance committee that has the power (...) and you have to work much harder to gain political influence if you are not a member of the finance committee'. But another councilor from the majority party who was formerly a member of the finance committee remarked 'It's bollocks' about this notion of being excluded. A councilor from the opposition who also stood down from the finance committee explained that you lose a lot of information and influence, but added that she had regained her political freedom as she was no longer bound by joint decisions.

A third problem is that the model presupposes that the party leaders in the finance committees can secure political support from their party members, but this becomes difficult when party leadership is renewed and the old, experienced and powerful party leaders are replaced by less experienced and less powerful ones. Local elections may be followed by increased political volatility as evidenced by events in the spring of 2018 when the mayor suddenly lost support in an important matter.

Finally, the model works well when all parties are represented in the finance committee, but after the last election in 2017, two small parties are no longer part of the finance committee and that has spoiled the consensus-building process as the two outsider parties have no ownership over the recommendations that are laid before the council, and are busy grinding their knives and sharpening their political profiles. As a result, political contestation is intensifying. As a countermeasure, the mayor intends to create a forum for discussion among all the party leaders, but such a forum may end up competing with the finance committee and thus seems an awkward construction.

The assessment of the overall impact of the executive finance committee on the exercise of collective and holistic political leadership is relatively positive. The executive finance committee model distributes power among the political parties, thus making political leadership more collective, at least for those councilors who are members. It also creates a formal and informal arena for cross-cutting political decision-making, thus rendering political leadership more holistic. However, the councilors report that most of the sectorspecific recommendations from the administration and standing committees are endorsed by the finance committee, so the actual impact of the broad holistic discussions in the finance committee is limited.

The problem with the impact of the finance committee on political leadership is that most of the discussions take the recommendations from the standing committees as their starting point in the formal part of the meetings, and that many of these recommendations were originally formulated by the administration and have limited political content and few policy implications. One of the executive administrators claimed that 'the councilors in the finance committee are good at keeping their focus on the political aspects rather than resorting to case processing', but another councilor complained that the administration was very powerful and suggested that 'we politicians should be involved earlier in the policy process, before the administration defines the premises and the direction'. The latter indicated that there was still some way to go before politicians become the drivers of policy development. However, as reported above, there is some room in the finance committee for informal political discussions of new and upcoming events and initiatives, and of how the municipality should respond to these. These discussions enhance the councilors' ability to exercise political leadership, especially that of the mayor who is often the one who executes the joint decisions. Nevertheless, as we have also seen, there is not much focus on exploring new policy issues and formulating new policy solutions in informal and open-ended discussions. It is more about putting out fires than developing new political solutions that bring the local community forward. 


\section{Hedensted Municipality}

The councilors in Hedensted spend most of their time in council and committee meetings. The council meetings are supplemented with thematic meetings based on input from the administration, followed by a Q\&A session. The political informants agreed that the council meetings are not an arena for policy-making. Most decisions are passed based on recommendations from the administration that are subsequently adopted by the standing committees, and there is hardly any political discussion, except for the occasional parading of party political opinions to please the local media. The informants also tended to agree that the thematic meetings merely served to prepare the councilors for future policy discussions by providing relevant information about new national legislation, empirical trends in public performance, and initiatives taken by the administration, and perhaps by neighboring municipalities, in dealing with a particular problem.

To the extent that the local councilors are involved in political decision-making, this takes place in the standing committees, which discuss policy recommendations made by the administration before passing their 'own' recommendations to the council. However, there is an imminent risk that the committee members drown in sector-specific case processing in the standing committees and focus only on problems within the narrowly defined policy areas that their standing committee is responsible for. A leading councilor explained:

'During the election campaign I listened to a lot of engaged politicians with good and strong visions for the municipality, and then after the election when we had constituted the council and were sitting in the political committee meetings, all these visions died out. There is no outlet for visions and political ideas because we just sit on these highly confined committees with an agenda set by the administration and the committee chair. We have to break down these narrow political silos to be able to discuss politics in a visionary way'

The problems of lack of space for political debate and the development of tunnel vision in political silos are mentioned by most of our informants. To avoid these problems, the elected council established a so-called 'dialogue meeting', which is a new form of meeting in which the local councilors meet prior to the parallel monthly meeting in the standing committees in order to discuss cross-cutting policy issues.

To fully understand the background for this policy innovation, we must go back to 2007, when three small municipalities were merged to form Hedensted Municipality. The financial crisis placed severe budgetary strains on the newly formed municipality and the elected council struggled to make ends meet. In 2011, it decided to spur 'radical innovation' to get more out of the shrinking budget. Radical innovation proved to be difficult because it fostered serious conflicts, but the municipality learned that holistic thinking and the involvement of relevant and affected actors were crucial to create new and better solutions. In 2014, the city council agreed on a new municipal strategy for 'sustainable welfare' that basically assumes that social welfare is provided through the vertical co-creation of welfare as a result of the mobilization of citizens and stakeholders; and through the horizontal co-creation of welfare based on collaboration across administrative and political silos. With respect to the latter, the municipality reshuffled its administrative departments to match different life phases that the citizens pass through: education, employment, physical infrastructure, culture and leisure, and social care. This administrative reorganization helped to combat the silo problem, but at the political level there was still a need for a forum in which the councilors could design holistic policy solutions to cross-cutting policy problems. The prompt response to this need was the institutionalization of the 'dialogue meeting'. 
The dialogue meeting is held two hours before the parallel standing committee meetings. It is a relatively informal meeting that takes place in the city hall canteen. Tea, coffee and cake are served and there is free seating around coffee tables. The meeting is closed to the public, thus creating a space for informal political discussions amongst the elected councilors. The executive public managers, including the administrative CEO, are present during the meeting. They are allowed to speak in order to provide relevant information and feasibility judgements, but they humbly try to stay in the background since the meeting is meant to be for the politicians. On a few occasions, guests from the local community have been invited to participate in a particular discussion.

In dialogue meetings, politicians rather than the administration set the agenda. The councilors can put new issues on the agenda through a digital online system right up until the beginning of the meeting. They may also instruct the administrative CEO to add an agenda item on their behalf. When adding an agenda item, the councilors can also choose a particular dialogue form, such as speaker's corner, panel session, group discussion or party-based deliberation. The local politicians then engage in an open-ended discussion of the agenda items, one by one. The discussion is moderated by administrators with particular facilitation skills. Unlike the council and committee meetings where the stack of meeting papers is tall, there are no preparatory documents on the table in dialogue meetings, which are referred to as 'blank paper meetings'.

Dialogue meetings are not formal decision-making arenas, but the politicians may informally decide whether to continue a particular discussion in an ordinary, or thematic, council meeting or in the parallel standing committee meetings where the councilors may visit another committee to discuss cross-cutting issues. They may also conclude a political discussion by initiating a co-creation process with external actors and setting up a problem-focused ad hoc committee under $\S 17.4$ in the Local Government Act.

The dialogue meeting is a forum for collective political discussions across ranks, parties and committees, and it has an interesting and positive political dynamic. One of the councilors said: 'The starting point is not administrative recommendations that we are expected to discuss and endorse, but things that we ourselves have put on the agenda'. Several councilors praised the fact that everyone could raise a political issue they were concerned about for personal or political reasons. They also applauded the fact that the members of the different party groups did not have time to coordinate their views, but were forced to speak their minds. Several councilors talked about how nice it was to 'be set free'. All in all, the councilors' control over the agenda and the problem-focused and open-ended character of the meetings tend to stimulate political discussion based on political values, opinions and ideas.

The fact that the councilors meet across the standing committees means that they can discuss issues that cut across different policy areas or bear no clear relation to a specific committee. Several informants reported that the standing committees often discuss issues that were brought up in the dialogue meeting in subsequent committee meetings in order to offer their specific perspective on a broader policy issue.

The drivers for the political discussions in the dialogue meetings are reportedly 'curiosity', 'political engagement' and the wish to 'influence the overall direction of the municipality' by 'playing a role early on in the political agenda setting'. Several informants reported that there was more room for engaged and explorative political discussions in the dialogue meetings than in the council and committee meetings, which are more steered by the administration.

A concrete barrier to the success of the dialogue meetings is that they are added to an already long list of meetings. As a result, the councilors' time budget becomes increasingly strained, and there are sometimes several absentees in the informal dialogue meetings, which tends to undermine joint ownership over new policy initiatives. 
Another barrier is that not all councilors are equally good at raising issues for debate. Hence, sometimes the items on the agenda are so few and of so little consequence that the dialogue meetings develop into a cozy talk-shop rather than being a vehicle for policy development. The councilors explained that in the midst of a busy life it was difficult to remember to put things on the agenda, and the administrators speculated that the problem was that the elected politicians were not used to setting the political agenda and initiating policy development. For that reason, the dialogue meetings were considered a training ground, even after four years.

Some councilors told us that besides providing space for political debate, which creates joint ownership over problems and solutions, the dialogue meetings also helped them to get to know each other across parties and committees, enabling them to become a team that can exercise leadership. The dialogue meetings also seem to benefit minority parties with only one council member because party size is less important in the dialogue meetings in which everybody can participate and raise issues of concern on an equal footing. Most of the political informants praised the fact that the lack of preparatory party group meetings results in a more open, engaged and creative discussion.

Some councilors refer to a potential drawback of the dialogue meetings. The initial political position that the political parties adopt in the dialogue meetings may change later on and create doubts about the party line. Occasionally, such changes give rise to political teasing in formal council meetings, but generally it is accepted that the political views expressed in dialogue meetings are not binding and may be subject to change.

The dialogue meetings tend to make local politics more consensual, which may constitute a problem for smaller parties, especially if they are to the Left and the voters expect them to have a sharp and critical political profile and engage in political contestation. However, the political consensus appears to have its limits since there have been some political conflicts over the budget, over the tendency to prioritize business promotion over social issues, and over how much administrative responsibility should be devolved to local service institutions.

A third drawback is that political issues raised in the dialogue meetings do not always reach the formal political arena in terms of council meetings. There is a risk that controversial ideas or policy proposals with limited support are nipped in the bud, or that it is decided that the administration should look further into something that never comes up again in council discussions or committee meetings. Hence, the dialogue meeting can be used to defuse 'bombs' and to legitimize administrative politics.

Finally, the local press complain that they are not allowed to report from the dialogue meetings and have retaliated in a rather paradoxical manner by reducing their coverage of the council meetings, thus reducing democratic transparency compared to before. The local councilors insist on the closed meetings because they think it gives them space for creative policy development across parties and committees, and they fear that these positive dynamics would be ruined if the press were present.

In terms of the overall impact of the innovative institutional design, the politicians were very positive about the dialogue meetings. An executive administrator reported that despite initial opposition from one of the political parties in particular, today they all love the dialogue meetings and nobody wants to abandon them. This overall assessment was confirmed by the councilors. One of them claimed that: 'The first Monday when we have the dialogue meetings is the most interesting day for me as a politician (...) You can turn up and say that you have been thinking about some important problem or issue and ask what the others think and whether we should do something about it. We are not prepared for this discussion in the party groups so we tend to get a very open and frank political debate'. Another claimed that: 'We have 
become far more agenda setting than before and much better at drawing in other people than those from the administration in our policy debates'. These and other similar quotations bear evidence of the positive impact that the dialogue meetings have on the exercise of political leadership. As we have seen, dialogue meetings stimulate political discussion. The fact that all councilors can raise issues and participate in the political debate gives political leadership a collective character, and the fact that the discussions cut across the often specialized sector-specific discussions in standing committees adds a holistic dimension to political leadership. In sum, there is little doubt that the dialogue meetings have promoted collective and holistic political leadership.

\section{Cross-case comparison}

The two municipalities use different institutional designs to realize their shared ambition to enhance collective and holistic political leadership. In Esbjerg, the political deliberations take place in a relatively formal decision-making arena in the form of the finance committee which, in accordance with the Local Government Act, has executive status and brings together all the party leaders in making the final recommendations to the elected council. However, there is also some room for informal political discussions in the meetings. In Hedensted, the political deliberations take place in a more informal forum that is not regulated by the Local Government Act, but is a local invention that brings together all councilors to discuss policy issues that they have raised themselves. The councilors have open-ended discussions about these issues before deciding whether, where and how to continue the discussion.

The drivers, barriers, benefits and drawbacks associated with the two different institutional designs are displayed in table 2 .

Table 2: Comparison of drivers, barriers, benefits and drawbacks

\begin{tabular}{|c|c|c|}
\hline & Esbjerg Municipality & Hedensted Municipality \\
\hline Drivers & $\begin{array}{l}\text { Wish to integrate and gain support } \\
\text { from councilors from different } \\
\text { parties by involving them in cross- } \\
\text { cutting, executive decision-making }\end{array}$ & $\begin{array}{l}\text { Wish to stimulate policy innovation } \\
\text { by involving all councilors in } \\
\text { explorative, agenda-setting policy } \\
\text { discussions at an early stage }\end{array}$ \\
\hline Barriers & $\begin{array}{l}\text { - Strong administrative control and } \\
\text { organizational silos } \\
\text { - Many extra meetings strain the } \\
\text { councilors' time budget }\end{array}$ & $\begin{array}{l}\text { Many extra meetings strain the } \\
\text { councilors' time budget } \\
\text { - Not all councilors participate in the } \\
\text { non-mandatory meetings }\end{array}$ \\
\hline Benefits & $\begin{array}{l}\text { - } \text { Creates shared political } \\
\text { responsibility by giving the } \\
\text { opposition more influence } \\
\text { - Produces a good administrative flow } \\
\text { and provides a solid anchorage } \\
\text { point for the administration }\end{array}$ & $\begin{array}{l}\text { The councilors get to know each } \\
\text { other and develop a team spirit } \\
\text { - Minority parties are listened to and } \\
\text { have greater influence } \\
\text { - More open, engaged and creative } \\
\text { policy discussions }\end{array}$ \\
\hline Drawbacks & $\begin{array}{l}\text { - Difficult to make tough decisions } \\
\text { - Creates a division between an A- } \\
\text { and a B-team } \\
\text { - Party leaders cannot always secure } \\
\text { support from their party group }\end{array}$ & $\begin{array}{l}\text { - Initial political positions may shift } \\
\text { later on } \\
\text { - Consensual politics clashes with } \\
\text { fringe parties' need for contestation } \\
\text { - No guarantee that initiated policies }\end{array}$ \\
\hline
\end{tabular}




\begin{tabular}{|l|l|l|}
\hline & $\bullet \begin{array}{l}\text { The model is destabilized if not all } \\
\text { parties are represented }\end{array}$ & will have executive impact \\
\hline
\end{tabular}

The different institutional designs in the two municipalities both seem to promote more collective and holistic political leadership by bringing the local councilors together in a forum for political debate and decision-making that cuts across parties and sectors. However, there are some clear differences in the impact of the dialogue meetings compared to the executive finance committee meetings. First, whereas the dialogue meetings are inclusive and egalitarian, the finance committee establishes a clear division between A- and B-team politicians, and tends to exclude the latter from collective and holistic political leadership. Second, whereas the finance committee meetings focus on policy execution, the dialogue meetings focus on policy initiation and development. This difference has an important consequence for political leadership. Hence, the dialogue meetings in Hedensted support all three components of political leadership in terms of problem identification, solution design and mobilization of support, while the finance committee meetings merely focus on the mobilization of political support across the political parties. In sum, the executive focus in the finance committee seems to prevent an open-ended discussion of the nature and character of different policy problems and a joint search for new solutions. Both of these defining components of political leadership are key elements of the dialogue meetings.

Let us conclude the comparison by highlighting three shared problems. The first problem is that both the dialogue meetings and the executive finance committee meetings are relatively disconnected from local citizens and stakeholders. As such, mobilization of political support mainly takes place within the group of elected councilors and does not involve local community actors.

The second problem is that both in the dialogue and finance committees, meetings are closed to the public. The institutional design of these kinds of meeting may enhance political leadership, but at the expense of democratic transparency. This trade-off is a true dilemma since the political discussions would surely be less open and frank if the media were present.

The third problem is that collective political leadership based on consensus-seeking across the aisle may hamper political accountability based on the presence of a critical opposition. If all councilors are equally responsible for public policy-making, then nobody can be held to account.

\section{Discussion and lessons learned}

Although the need for, and pressure on, local political leadership is widespread, and the tendency for political leadership to become individualized, fragmented and confined to sector-specific silos is ubiquitous, attempts to enhance collective and holistic political leadership through institutional design are few and far between and seldom subject to in-depth studies. The results of our study show that different institutional designs may serve the same purpose of strengthening political leadership through joint and cross-cutting policy deliberations.

Four lessons can be drawn from the comparative analysis of Esbjerg and Hedensted. The first lesson is that both formal 'constitutional' arenas such as the executive finance committee, and informal and locally invented forums such as the dialogue meetings, can provide spaces for the exercise of a more collective and holistic form of political leadership. Hence, local governments may create their own tailor-made institutional designs if no formal authoritative option is provided by legislation. 
The second lesson is that new institutional designs require active support both from politicians and administrators. Obviously, the new institutional arrangements will not be successful without support from the councilors, but executive administrators must also be on board. In Esbjerg, the administrators' support is motivated by benefits they receive in terms of better administrative flow and clear political direction. In Hedensted, administrative support is stronger and more active because the administration played a key role in the design of the new institutional arrangement. Hence, the dialogue meetings were a result of cocreation, which has been paramount for their success.

The third lesson is that the executive focus of the political deliberations in the finance committee hampers its positive impact on political leadership, compared to the agenda-setting focus of the dialogue meetings. The finance committee only brings together the party leaders, and excludes two thirds of the councilors from the collective and holistic policy discussions. Its agenda is defined by the administrative-political recommendations made by the sector-specific committees, thus placing severe limits on holistic policymaking. Finally, the focus on the mustering of inter-party support for executive decisions means that there is little focus on problem definition and solution design, which are core aspects of political leadership. By contrast, the dialogue meetings take place before the negotiations in the standard committees, thus ensuring that political deliberations are open-ended, and they involve all councilors in cross-cutting policy discussions which aim to set the agenda, explore problems and solutions, and build joint ownership. However, the problem is that there is no guarantee that the issues discussed in the informal discussion forum will reach the formal decision-making arenas. Still, the institutional design in Hedensted seems to have a greater and more positive effect on the enhancement of collective and holistic political leadership.

The fourth lesson is that the different institutional designs enhancing collective and holistic political leadership are not necessarily compatible with democratic norms of transparency and participation. This lesson draws our attention to the fundamental tension between political leadership based on struggles for hegemony between government and opposition at the apex of the political-administrative system, and democracy which involves a horizontal dispersion of power and transparent decision-making (Kane and Patapan, 2012).

While the three first lessons have direct relevance for local councils aiming to reform their political institutions in order to enhance collective and holistic political leadership, the fourth lesson calls for further research and experimentation in order to explore how the democratic deficit of political leadership reforms can be counteracted.

\section{Conclusion}

Through democratic elections, we elect local political representatives and entrust them to find solutions to societal problems on our behalf. We expect local councilors to exercise political leadership by defining problems and designing and implementing solutions. When councilors fail to exercise political leadership, political power is concentrated in the hands of strong mayors or executive public administrators, and attempts to involve the elected councilors in political decision-making through the introduction of committee systems tends to confine policy-making to intra-sectoral decisions prompted by administrative cues. To remedy these problems, some Danish municipalities have aimed to foster a more collective and holistic style of political leadership by changing their institutional designs.

We undertook a comparative analysis of the efforts of two Danish frontrunner municipalities in order to see whether it is possible to use institutional design to enhance collective and holistic political leadership. We found that institutional design is effective in promoting collective and holistic political leadership at the 
local level, even if no formal design options are available and the municipalities have to invent their own designs. Support both from councilors and administrators is paramount for successful implementation.

The comparative analysis revealed that the exercise of collective and holistic political leadership requires the formation of collective forums in which local councilors can make political decisions together that cut across sector boundaries, enabling them to see the bigger picture. Preferably, the councilors should be able to participate both in the problem definition and the design of solutions through a combination of formal and informal decisions that support creative problem-solving.

It is impossible to generalize about these Danish experiences, since they are conditional on the presence of relatively strong local councils in relatively large municipalities where the political stakes are high and councilors have a lot to gain from institutional reforms. However, practitioners may seek inspiration in local experiments that demonstrate the positive impact of institutional reform on political leadership.

Research in this area is scarce, but future studies could identify further cases of local councils using institutional reforms to enhance collective and holistic political leadership. Analyzing the impact and scope conditions of such reforms may help to strengthen local democracy, which hinges on the exercise of a collective leadership style that involves all councilors in holistic discussions about problem framing, the design of innovative, yet feasible, policy solutions, and the creation of joint ownership. Empirical studies of local institutional reforms might also pay attention to how such reforms find new ways of involving local citizens and stakeholders, thus addressing not only the problems of decoupling and tunnel vision, but also the relative isolation of local councilors.

Although this research focused on local government, the challenges to political leadership are almost identical at the regional and national level. We see a growing number of reform initiatives at the level of national government (Beetham, 2006, 2011), some of which are trying to create new forums for joint political debate and cross-cutting problem solving. Comparisons between local and national level reforms may serve to deepen our understanding about how democratic political leadership can be strengthened through institutional design.

\section{References}

Ayres, S. (2017), 'Assessing the Impact of Informal Governance on Political Innovation', Public Management Review, 19(1): 90-107.

Bache and Flinders (Eds) (2004), Multi-level Governance, Oxford: Oxford University.

Barber, B. (2013), If Mayors Ruled the World, New Haven: Yale University Press.

Beetham, D. (2006), Parliament and Democracy in the 1st Century, Geneva: Inter-parliamentary Union.

Beetham, D. (2011), 'Do Parliaments have a Future?', in S. Alonso, J. Keane, and W. Merkel (Eds), The Future of Representative Democracy, Cambridge: Cambridge University Press, 24-43.

Bentzen, Lo and Windsvold (2019), 'Local institutional changes in local democracy in Denmark and Norway', Local Government Studies, Forthcoming.

Berg, R. (2005), 'From cabinets to committees: The Danish experience', in R. Berg and N. Rao

(Eds), Transforming Political Leadership in Local Government, Basingstoke: Palgrave-MacMillan, 85-100. 
Berg, R. and Rao, N. (Eds) (2005), Transforming Political Leadership in Local Government, Basingstoke: Palgrave-MacMillan.

Bryson, J. M. and Crosby, B. C. (2005), Leadership for the Common Good, Hoboken, NJ: John Wiley \& Sons. Burns, J. M. (1978), Leadership, New York: Harper and Row.

Dalton, R. J. and Welzel, C. (Eds) (2014), The Civic Culture Transformed: From Allegiant to Assertive Citizens, Cambridge: Cambridge University Press.

Elcock, H. J. (2001), Political Leadership, Cheltenham: Edward Elgar.

Goodin, R. E. (Ed.) (1998), The Theory of Institutional Design, Cambridge: Cambridge University Press.

Helmke, G. and Levitsky, S. (2004), 'Informal institutions and comparative politics: A research agenda', Perspectives on Politics, 2(4): 725-740.

Kane, J. and Patapan, H. (2012), The Democratic Leader. How Democracy Defines, Empowers, and Limits its Leaders, Oxford: Oxford University Press.

Karsten, N. and Hendriks, F. (2017), 'Don't call me a leader, but I am one: The Dutch mayor and the tradition of bridging-and-bonding leadership in consensus democracies', Leadership, 13(2): 154-172.

Keohane N. O. (2014), 'Western Political Thought', in R. A. W. Rhodes and P. 't Hart (Eds), The Oxford Handbook of Political Leadership, Oxford: Oxford University Press, 25-40.

Kjær, U. and Opstrup, N. (2016), Variationer I udvalgsstyret: Den politiske organisering i syv kommuner, Copenhagen: Kommuneforlaget

KL (2018)

Machiavelli, N. (1961), The Prince, London: Penguin.

March, J. G., and Olsen, J.P. (1995), Democratic Governance, New York: The Free Press.

Mouritzen, P. E. and Svara, J. H. (2002), Leadership at the Apex: Politicians and Administrators in Western Local Governments, Pittsburgh: University of Pittsburgh Press.

Nye, J. (2008), The Powers to Lead, Oxford: Oxford University Press.

Osborne, D., and Gaebler, T. (1992), Reinventing Government: How the Entrepreneurial Spirit is Transforming Government, Reading: Adison Wesley.

Peters, B. G. (2012), Institutional Theory in political Science, London: Bloomsbury Publishing. $3^{\text {rd }}$ edition.

Pierre, J. and Peters, B. G. (Eds) (2004), The Politicization of the Civil Service, London: Routledge.

Rao, N. (2005), 'From committees to leaders and cabinets: The British experience', in R. Berg and N. Rao (Eds), Transforming Political Leadership in Local Government, Basingstoke: Palgrave-MacMillan, 42-58.

Smith, G. (2009), Democratic innovations, Cambridge: Cambridge University Press.

Stone, C. (1995), 'Political leadership in urban politics', Theories of Urban Politics, London: Sage, 96-116.

Sørensen, E. (2017), 'Innovations in political institutional arrangements, processes and outputs', Public Management Review, 19(1): 1-19. 
Sørensen, E. and Torfing, J. (Eds) (2007), Theories of Democratic Network Governance, Basingstoke: Palgrave-MacMillan.

Sørensen, E. and Torfing, J. (2013), 'Kommunalpolitikere som ledere af politikinnovation', Økonomi og Politik, 86(4): 33-47.

Sørensen and Torfing (2019), 'Towards robust hybrid democracy in Scandinavian countries?', Scandinavian Political Studies, forthcoming.

't Hart, P. and Uhr, J. (Eds.) (2008), Public Leadership: Perspectives and Practices, Canberra: ANU Press.

Tucker, R. C. (1995), Politics as Leadership, Missouri: University of Missouri Press.

Weber, M. (1978), Economy and Society (vol. 1), Berkeley: University of California Press.

Wollmann, H. (2005), 'The directly elected executive mayor in German local government', in R. Berg and N. Rao (Eds), Transforming Political Leadership in Local Government, Basingstoke: Palgrave-MacMillan, 29-41. 